\title{
Musculoskeletal Frailty: A Geriatric Syndrome at the Core of Fracture Occurrence in Older Age
}

\author{
E. Gielen · S. Verschueren - T. W. O'Neill • S. R. Pye • M. D. L. O'Connell • \\ D. M. Lee $\cdot$ R. Ravindrarajah $\cdot$ F. Claessens $\cdot$ M. Laurent $\cdot$ K. Milisen $\cdot$ \\ J. Tournoy $\cdot$ M. Dejaeger $\cdot$ F. C. Wu $\cdot$ D. Vanderschueren $\cdot$ S. Boonen
}

Received: 7 December 2011/Accepted: 27 April 2012/Published online: 14 July 2012

(C) Springer Science+Business Media, LLC 2012

\begin{abstract}
A progressive decline in physiologic reserves inevitably occurs with ageing. Frailty results from reaching a threshold of decline across multiple organ systems. By consequence, frail elderly experience an excess vulnerability to stressors and are at high risk for functional deficits and comorbid disorders, possibly leading to institutionalization, hospitalization and death. The phenotype of frailty is referred to as the frailty syndrome and is widely recognized in geriatric medical practice. Although frailty affects both musculoskeletal and nonmusculoskeletal systems, sarcopenia, which is defined as age-related loss of muscle mass and strength, constitutes one of the main determinants of fracture risk in older age and one of the main components of the clinical frailty syndrome. As a result,
\end{abstract}

E. Gielen and S. Verschueren contributed equally to this article, and both should be considered first author.

The authors have stated that they have no conflict of interest.

E. Gielen · M. Laurent $\cdot$ J. Tournoy $\cdot$ M. Dejaeger .

S. Boonen $(\bowtie)$

Gerontology and Geriatrics Section, Department of

Experimental Medicine, KU Leuven, Leuven, Belgium

e-mail: steven.boonen@uzleuven.be

S. Verschueren

Research Centre for Musculoskeletal Rehabilitation, Department of Rehabilitation Sciences, KU Leuven, Leuven, Belgium

T. W. O’Neill · S. R. Pye · D. M. Lee

Arthritis Research UK Epidemiology Unit, Manchester

Academic Health Science Centre (MAHSC), University

of Manchester, Manchester, UK

M. D. L. O'Connell · R. Ravindrarajah · F. C. Wu

Andrology Research Unit, Manchester Academic Health Science

Centre (MAHSC), University of Manchester, Manchester, UK operational definitions of frailty and therapeutic strategies in older patients tend to focus on the consequences of sarcopenia.

Keywords Comprehensive geriatric assessment · Frailty · Muscle mass · Muscle strength - Osteoporotic fracture . Sarcopenia

\section{Introduction}

A progressive decline in physiologic reserves inevitably occurs with ageing. Frailty results from reaching a threshold of decline across multiple organ systems, and leads to an excess vulnerability to stressors and a decreased ability to maintain homeostasis after a destabilizing event [1]. After exposure to stressors, frail elderly encounter more functional deficits and are at higher risk for comorbid disorders [1]. This combination of functional deficits and

\author{
F. Claessens · M. Laurent \\ Laboratory of Molecular Endocrinology, Department \\ of Molecular Cell Biology, KU Leuven, Leuven, Belgium \\ K. Milisen \\ Centre for Health Services and Nursing Research, KU Leuven, \\ Leuven, Belgium \\ D. Vanderschueren \\ Experimental Medicine and Endocrinology Section, Department \\ of Experimental Medicine, KU Leuven, Leuven, Belgium
}


comorbid disorders constitutes the frailty syndrome, the widely recognized clinical phenotype of frailty. A key component in the frailty syndrome is sarcopenia, the loss of muscle mass and strength with ageing. The aim of this article is to review the concepts of frailty and sarcopenia, including their definition, classification and approaches to treatment and prevention.

\section{Sarcopenia}

Originally, sarcopenia has been described as the age-related loss in muscle mass [2]. Currently, the term mostly refers to the loss of muscle mass and muscle strength that is associated with ageing [3]. Sarcopenia results in a decrease in aerobic capacity of about $10 \%$ per decade from the age of 25-30 years, through which, in older people, activities of daily living (ADL) will demand efforts that are close to their limiting capacity. Consequently, sarcopenia is linked with disability [4], loss of mobility [5], impaired (static and dynamic) balance [6], and an increased risk of falls [7], fractures [8], and even death [9].

\section{Age-related Change in Muscle Mass and Muscle} Strength

In longitudinal studies, muscle mass decreases by around $40 \%$ between the age of 20 and 60 , with an average loss of $1 \%$ per year [10]. The absolute decrease is more pronounced in men than women, though relative loss is comparable as men initially have more muscle mass [11].

The difference in muscle strength at 20-40 years and at $70-80$ years of age varies between 20 and $40 \%$ in crosssectional studies. At age 90 and over there is further loss of muscle strength up to $50 \%$ or more [12]. In longitudinal studies, muscle strength decreases more rapidly, up to $3 \%$ per year. As with the decrease in muscle mass, the relative loss of muscle strength in men and women is comparable, though again the absolute loss is larger in men, who initially have greater muscle strength. In contrast to loss of muscle mass, which mainly occurs in the lower limbs, the loss of muscle strength in the upper and lower limbs is comparable [13].

With respect to the mechanisms leading to the agerelated loss of muscle mass and strength, an increase of catabolic and a decrease of anabolic processes can be distinguished [12]. The first category includes low-grade immunologic changes, which occur with ageing even in the absence of inflammatory processes and which may contribute to muscle protein breakdown. Apart from the relationship between low muscle performance and high levels of proinflammatory substances during acute inflammation [14], an association has indeed been shown between lower muscle mass and strength and a chronic, age-related increase in white blood cells, C-reactive protein (CRP) and proinflammatory cytokines like tumor necrosis factor- $\alpha$ (TNF- $\alpha$ ) and interleukin-6 (IL-6) [15]. Alterations in the levels of anabolic hormones, such as a decline in sex hormones [16, 17], vitamin D deficiency [18], changes in the growth hormone/insulin-like growth factor-1 (GH/IGF-1) axis [19] and insulin resistance [20] may also play a role in the development of sarcopenia. Insulin resistance for example is associated with low muscle mass and strength as it impairs the synthesis and increases the breakdown of muscle proteins, reduces the uptake and intracellular metabolism of glucose, and induces chronic inflammation [21]. On its turn, chronic inflammation may be a mechanism for insulin resistance. Age-related myocellular changes, including apoptosis of myofibers and a decreased number of satellite cells, which replace damaged myofibers, may contribute to sarcopenia as well [22]. Finally, also physical inactivity and insufficient protein intake due to anorexia of ageing and cachexia in chronic diseases and malignancy are associated with loss of muscle mass and strength [23].

The loss of muscle strength with ageing has been thought to be a direct result of the age-related loss in muscle mass. However, as mentioned before, the decline in muscle strength is greater than the decline of muscle mass, with suggests that loss of muscle strength is only partially due to loss of muscle mass and that other factors than low muscle mass may contribute to muscle weakness [24, 25]. In a longitudinal study, changes in muscle mass indeed explained only $5 \%$ of the change in muscle strength [26]. Other muscular and also neurological mechanisms have been suggested to account for the major part of the agerelated loss in muscle strength, including, amongst others, reduced cortical and spinal excitability, a decline in the number and size of motor units, age-related remodeling of motor units, excitation-contraction uncoupling and increased fat infiltration in the muscles [10, 24].

\section{Definition of Sarcopenia}

An operational definition of the concept sarcopenia, that provides a threshold for targeting treatment and inclusion in trials, is required in clinical and research practice. However, until now, there is no consensus about such a definition of sarcopenia.

Analogous to the definition of bone loss (osteoporosis), sarcopenia has been defined using a threshold based on the distribution of muscle mass in young healthy adults. Thus, it has been defined as a relative appendicular skeletal muscle mass (RASM, muscle mass of arms and legs [kg] divided by height ${ }^{2}\left[\mathrm{~m}^{2}\right]$ ) less than two standard deviations below the mean of a same sex young healthy reference 
group [3]. Appendicular skeletal muscle mass can be measured accurately using computed tomography (CT) or magnetic resonance imaging (MRI). Determination of muscle mass using these tools, however, is restricted to research purposes because of costs and availability and also, in the case of $\mathrm{CT}$, radiation exposure. In clinical practice, dual-energy X-ray absorptiometry (DXA) is used for measuring muscle mass [27]. An alternative for DXA is bioelectrical impedance analysis (BIA); the results under standardized conditions correlate well with MRI findings and there are established reference values for older people [28]. Assessment of muscle mass using anthropometric measurements based on the circumference and skinfold thickness of the upper arm has been used, though agerelated changes in body composition and elasticity of the skin make the results difficult to interpret [27].

As discussed above, muscle strength is largely independent of muscle mass and so defining sarcopenia purely on the basis of a reduction in muscle mass has been considered to be inappropriate. Therefore, some have suggested that additional criteria are needed. On the basis of the recommendations of the European Working Group on Sarcopenia in Older People (EWGSOP), at least one criterion of low muscle function (low muscle strength or poor physical performance) must be met in addition to the low RASM criterion for the diagnosis of sarcopenia. The EWGSOP recommends that a person fulfilling only the criterion of low RASM should be classified as presarcopenic, while a person who also meets one or two criteria of low muscle function is diagnosed with sarcopenia or severe sarcopenia, respectively [27]. The EWGSOP proposes different cutoff points for these three criteria, which vary according to the reference population and the techniques used to measure muscle mass, muscle strength and physical performance. Also other expert groups have been working on an operational definition of sarcopenia that includes a measure of low muscle function (usually low gait speed) in addition to low muscle mass [29-31].

Instead of adding the criteria of muscle function (muscle strength or physical performance) to low muscle mass, Clark and Manini have argued that the term sarcopenia should be limited to its original meaning of the age-related loss of muscle mass. To describe the decline of muscle strength associated with ageing, they proposed the concept dynapenia [24, 25]. One argument to distinguish sarcopenia (low muscle mass) from dynapenia (low muscle strength) is, as discussed, that the pathophysiology of loss of muscle strength is multifactorial, with muscle mass explaining only a small part of the variance in muscle strength. Another argument is that, although a formal metaanalysis comparing the relative influence of low muscle mass versus low muscle strength on physical disability and poor physical performance is still lacking, current evidence suggests that this association is more important for low muscle strength than for low muscle mass [25]. Also mortality was strongly related with muscle strength and this association could not be attributed to muscle mass [32]. Currently, there are no sufficient data to define cutoff points for dynapenia [25]. Clark and Manini argued against defining dynapenia on the basis of low muscle power (the rate of work per time) instead of low muscle strength [25]. Although muscle power correlates strongly with physical performance and decreases even faster with ageing compared to muscle strength [33-35], the rationale for not defining dynapenia based on muscle power is the conflicting evidence as to whether or not muscle power is a better predictor of physical performance. Although in some large studies on ageing, muscle power was better than muscle strength to predict physical performance [36, 37], other authors could not confirm this observation [38] or found such a small difference that the debate remains undecided [39]. Moreover, muscle power increased less with training as compared with muscle strength in some studies [40], and even when the increase in power was greater than the increase in strength, the improvement in physical performance was the same [41]. Reference values and equipment to measure muscle power are also less available than is the case for muscle strength.

The prevalence of sarcopenia depends on its definition, the technique used to measure muscle mass and strength, and the reference group [42]. Prevalence is also genderdependent and increases with age, from less than $5 \%$ between 50 and 65 years of age, up to $30 \%$ in women aged 80 and above and even $50 \%$ in men over 80 [43].

\section{Sarcopenic Obesity}

A specific condition is sarcopenia in obese elderly, known as sarcopenic obesity. Baumgartner defined this condition as having a $\%$ body fat ( $\%$ fat) above the median together with the aforementioned criterion of low RASM [44]. Other cut-points for obesity and low muscle mass have been proposed, resulting in a prevalence of sarcopenic obesity of between 4 and $12 \%$. When sarcopenic obesity was defined as a body mass index (BMI) higher than $30 \mathrm{~kg} / \mathrm{m}^{2}$ plus muscle strength in the lowest gender-specific tertile, the prevalence ranged between 4 and $9 \%$ [45].

Several mechanisms potentially link obesity and sarcopenia. Obese persons tend to be less physically active and have lower levels of anabolic hormones such as testosterone, GH and IGF-1. They also have higher levels of proinflammatory cytokines and adipokines (leptin, adiponectin and resistin) that induce chronic inflammation, which may trigger insulin resistance [15, 45]. All these conditions may lead to sarcopenia. 
Studies about the effect of sarcopenic obesity on disability and physical performance have provided inconsistent results when the sarcopenia component was defined as low muscle mass. When it was defined as low muscle strength (dynapenia), elderly persons with sarcopenic obesity had a higher prevalence of disability and physical impairment compared to those who were just obese or sarcopenic [46]. Also the risk on mortality was higher in overweight persons with low grip strength compared to those with a normal weight and high grip strength [47].

\section{Frailty}

As evidenced by longitudinal studies such as the Baltimore Longitudinal Study of Aging, normal ageing is accompanied by a number of physiologic changes, such as changes in the cardiovascular system and the musculoskeletal system [48]. Frailty can be described as an increased vulnerability with reduced resistance to stressors resulting from reaching a threshold of decline in physiologic reserves across multiple organ systems [1]. Because this decline is an inherent feature of ageing, the occurrence of frailty inevitably rises with age. However, frailty is not synonymous with ageing, as individual differences in organ reserves may protect against or mitigate the consequences of the decline. The size of the reserves determines the degree of frailty, with elderly people with low reserves being more vulnerable and prone to functional deficits and comorbid disorders [49].

This increased susceptibility to functional deficits and comorbidity results in a decline in ADL and instrumental ADL, loss of mobility, (recurrent) falls, fractures, hospitalization and institutionalization in frail elderly [50-56]. Frailty also increases the risk of mortality: compared to nonfrail elderly, frail persons were more likely to die in the following years, even after adjusting for demographic variables and underlying comorbidity [50-52, 54-56].

Thus, the increased frailty of older people predisposes to functional deficits and comorbidity. These, in turn, may contribute to the progression of frailty. Yet, frailty, functional deficits and comorbidity are distinct clinical entities [57]. On the one hand, not all frail people have functional deficits or comorbid disorders and on the other hand, functional deficits may be the consequence of other disorders, and comorbid disorders do not necessarily lead to frailty [58] (Fig. 1).

Deterioration of the musculoskeletal system-both sarcopenia and osteoporosis, or sarco-osteopenia [59]-has an important functional impact and weighs heavily on the clinical expression of frailty. However, frailty refers to the whole organism and should not be confined to musculoskeletal frailty, as a decline in nonmusculoskeletal organ

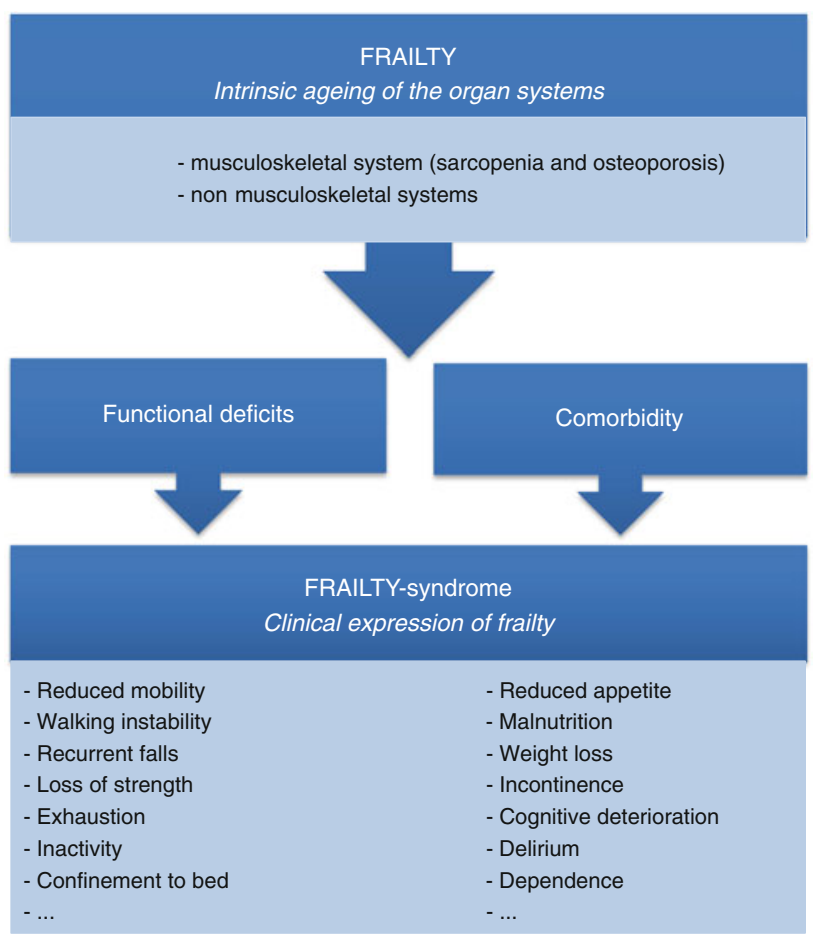

Fig. 1 The frailty concept and its clinical expression

systems contributes to frailty as well [60]. A recent comprehensive analysis has shown, for example, that the excess mortality after hip fracture, in contrast to what was assumed before, does not normalize after a vulnerable period of 6-12 months, a period in which especially medical complications after the traumatic event and surgery are paramount. Even after successful surgery and intensive revalidation, the prognosis remains relatively unfavorable, with mortality rates being three to fourfold higher than expected even after 10-15 years [61]. This reflects the underlying generalized vulnerability (rather than just musculoskeletal vulnerability) of such patients [62].

Mechanisms that Contribute to the Development of Frailty

Because deterioration of the musculoskeletal system is a key component of the frailty syndrome, the aforementioned pathophysiological mechanisms that lead to sarcopenia contribute to the development of frailty as well. However, as frailty is an organism-wide problem, one assumes that potential determinants of the frailty syndrome induce a catabolic cascade that also affects other tissues and organs (e.g., skin atrophy, heart failure), in addition to weakened bones and reduced muscle strength [63]. These determinants will be discussed hereafter. What should be emphasized is that the discussed mechanisms of frailty, to a 
certain degree, are mostly based on association studies and remain speculative.

The age-associated chronic low-grade inflammatory profile that, through its catabolic effect, plays a role in the development of sarcopenia, may contribute to frailty, as higher levels of white blood cells, proinflammatory cytokines and CRP have been observed in frail elderly [63, 64]. CRP is also associated with incident frailty in some [65], but not all trials [66]. Inflammation may be the result of oxidative stress, which has recently been linked with frailty [67]. Certain lifestyle and environmental factors increase the production of reactive oxygen species (ROS), which induces changes in gene expression and damage of DNA, proteins and lipids. This does not only give rise to more ROS, but also to inflammation and proliferation, necrosis and apoptosis at cellular level, ultimately leading to frailty [68]. In a recent study that explored the association between genetic variants and frailty, many of the genes associated with frailty were involved in the regulation of apoptosis, biosynthesis and transcription, rather than in inflammation [69]. This suggests that-more than inflammation-cellular senescence and apoptosis, including apoptosis of myofibers, may play a role in the development of frailty [22, 69].

Increased levels of biomarkers of coagulation and fibrinolysis have also been considered in the pathophysiology of frailty. Indeed, significantly higher levels of D-dimer and factor VIII have been observed in frail elderly, and higher levels of D-dimer and tissue plasminogen activator (t-PA) increased the risk on incident frailty $[64,66]$. Whether this means that frailty is directly linked with activated coagulation or decreased fibrinolysis is not clear, as these increased markers may also be the result of the aforementioned age-associated chronic inflammation [63].

Hormonal changes associated with sarcopenia may play a role in the development of frailty as well. With respect to the contribution of the age-related decline in sex hormones, studies have provided inconsistent results. Although some authors did not find a cross-sectional association between total or free testosterone and frailty [70], other authors did find such an association cross-sectionally [71-73] and longitudinally [72-74], although it disappeared in one of the longitudinal analysis adjusted for covariates [74]. The same applies to sex hormone-binding globulin (SHBG); SHBG was associated with frailty in some [70], but not all studies [74]. A possible explanation for the inconsistencies in these studies may be the different definitions of frailty. Frailty has also been linked with vitamin D deficiency [75]. Low levels of vitamin $\mathrm{D}(<20 \mathrm{ng} / \mathrm{mL})$ are associated with a higher odds of prevalent frailty [76, 77] and an increased risk of incident frailty [76]. The latter was, however, not consistent in all studies in men [77]. Low 25-OH-D may be associated with frailty through several biological pathways, including an effect on bone, muscle and the immune system [78]. Indeed, besides its well documented role in osteoporosis and fracture risk, vitamin D deficiency has been associated with low muscle mass and strength and an increased level of proinflammatory cytokines $[18,79]$. Also IGF-1 and insulin resistance may contribute to frailty, as frail elderly had lower IGF-1 levels than nonfrail agematched individuals and having insulin resistance increased the risk of incident frailty [21, 65].

Although frailty is often considered as a wasting syndrome, obesity does not protect against frailty. Quite the contrary, a U-shaped curve between BMI and frailty in elderly women suggests that not only underweight individuals, but also obese ones have an increased risk of frailty $[80,81]$. This can be explained by the fact that obese elderly may develop sarcopenia-musculoskeletal frailtythrough several mechanisms, which have been discussed before.

\section{Definition of Frailty}

Although most people recognize the clinical syndrome of frailty, it has proved difficult to agree to a consensus operational definition. A number of classification criteria have been proposed.

\section{Frailty Phenotype}

One of the most widely used operational definitions of frailty is that developed by Fried et al. [54]. Fried et al. proposed a phenotypic definition of frailty that consists of five components: unintentional weight loss, weakness, slowness, self-reported exhaustion (poor endurance) and low physical activity (Table 1). An individual is classified as frail if at least three of these criteria are met. Those with one or two criteria are classified as pre-frail and those with none, robust. Fried et al. used data from the Cardiovascular Health Study (CHS), a comprehensive analysis of 5,317 men and women aged 65 years and older to develop the criteria [82]. Unintentional weight loss was defined as an involuntary decrease in weight of at least $4.5 \mathrm{~kg}$ in the last year. Muscle strength was assessed as maximal grip strength (in kilograms) in the dominant hand (average of three measures), using a hand-held dynamometer. People had muscle weakness if their maximal grip strength was in the lowest quintile of the study population (adjusted for gender and body mass index). Walking speed was specified as the time needed to walk 15 feet at normal pace; slowness was defined as a value in the lowest quintile (adjusted for gender and standing height). People had poor endurance (exhaustion) if they agreed with either of two statements: "I felt that everything I did was an effort" or "I could not 


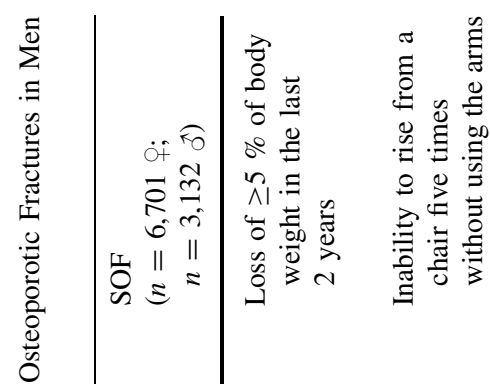

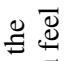

을

产苛

$\stackrel{\circ}{\circ}$.

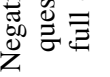

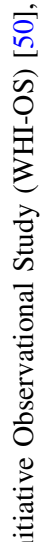

|

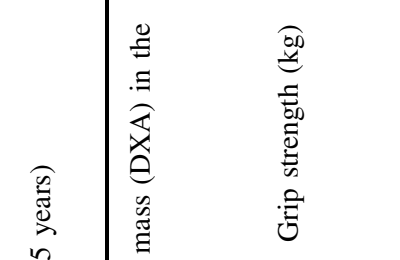

ิㅡㄴ

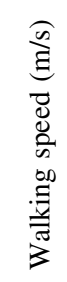

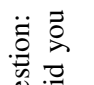

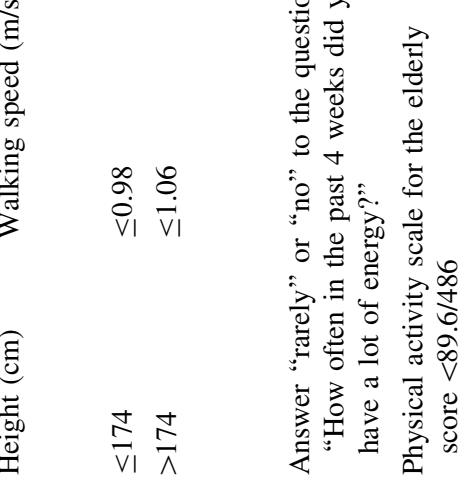

焉

운

范

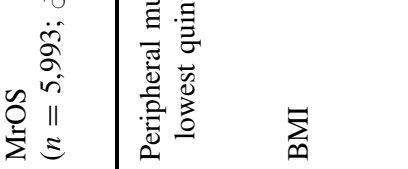

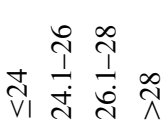

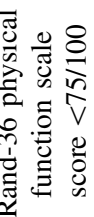

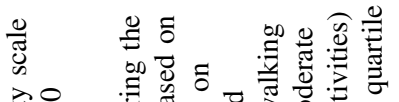

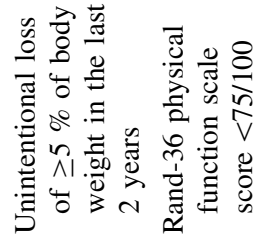

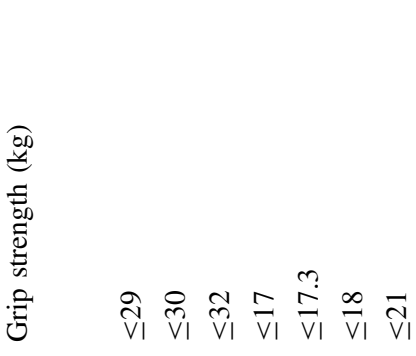


get going more than 3-4 days in the last week." An affirmative answer was indicative of decreased maximal oxygen consumption $\left(\mathrm{VO}_{2 \max }\right)$. Physical activity was estimated by questioning about 18 leisure activities during the last week. A weighted score of kilocalories expended per week was calculated on the basis of these questions. The lowest quintile of physical activity was identified for each gender and defined as low physical activity. The strength of the approach of Fried et al. lies in the ability of the criteria to predict clinical end points, including the risk for falls, decreased mobility, functional decline, hospitalization and even death in older adults [54].

Using a similar approach, others have adapted data from their own studies to develop a frailty phenotype [50, 55, 83-86] (Table 1). For example, in the frailty definition of the Women's Health Initiative Observational Study (WHIOS), muscle strength and walking speed were not determined by measurements, but by means of a questionnaire on physical function, the Rand-36 Physical Function Scale, which is considered to be a good alternative for muscle strength and walking speed assessments [50]. In the Osteoporotic Fractures in Men Study (MrOs), instead of weight loss over the last year, appendicular skeletal muscle mass by DXA was determined, which is a better measure for sarcopenia than recent weight loss because the latter may not accurately reflect changes in muscle mass, and muscle loss can be masked by a simultaneous increase in fat mass [83].

Others have proposed modified phenotypic definitions of frailty by either adding or subtracting criteria. To supplement the purely physical frailty phenotype by Fried et al., psychosocial factors have been proposed, like fear and loneliness or depressive symptoms, and even cognitive scores [87-89]. It remains unclear to what degree such additional factors may improve the predictive value of frailty on adverse health outcomes [90]. On the other hand, elements have been left out to render the frailty definition more usable in clinical practice. To establish thresholds for muscle weakness, slowness and low physical activity according to Fried et al., the distribution of these characteristics in the target population should be known and corrected for factors like height and weight. Additionally, some authors found the assessments of walking speed and physical activity infeasible in clinical practice because of space and time constraints [52]. Therefore, simplified frailty indices have been introduced in different studies [51, 52]. In the Study of Osteoporotic Fractures (SOF) index, only weight loss, muscle weakness and poor endurance were retained as criteria (Table 1). According to the SOFindex, weight loss was defined as the loss of body weight of $5 \%$ or more during a 2-year follow-up period. Muscle weakness was specified as the inability to rise from a chair five times without using the arms. Poor endurance was identified by a negative answer to the question, "Do you feel full of energy?" Individuals that met two or three criteria were considered to be frail, those with only one to be pre-frail and those with none to be robust.

A growing number of frailty scales has become available, though interestingly the clinical and research value of these indices seems comparable. The predictive value of the operational frailty definition of Fried et al. is similar to that of alternative indices in which the criteria from Fried et al. have slightly been adapted [50,55] or simplified [51, 52]. The simplified SOF index, for example, was able to predict the risk for falls, fractures, functional decline and mortality as well as the more detailed approach of Fried et al. [51, 52].

\section{Frailty Index}

The frailty phenotype of Fried et al. and modified phenotypic definitions outlined above characterize individuals into groups and consider a person frail if a certain number of criteria are present, with the focus largely on the musculoskeletal system. A separate approach, pioneered by Rockwood and colleagues in Canada, is the frailty index. In the frailty index, deficits, which have been identified by means of a comprehensive assessment, are quantified and used as a marker or index of underlying frailty. The index is expressed as the proportion of present deficits to the total number of potential deficits in an individual [91]. Dozens of items are thereby checked; symptoms, clinical findings and diseases, but also functional limitations and abnormal biochemical, electrocardiographic and radiographic findings can be included as deficits [92]. Whereas the definition of Fried et al. emphasizes functional deficits caused by frailty, the frailty index includes functional deficits as well as underlying comorbidity [91, 93]. A further advantage of the approach is that it seems to be robust to the number and type of deficits included. The frailty index has been shown to be predictive of a range of adverse outcomes including functional prognosis, hospitalization, institutionalization and mortality, and it correlates well with the phenotypic definition of Fried et al. [94]. However, it is more timeconsuming to implement.

\section{FRAIL Scale}

Recently, the International Academy of Nutrition, Health, and Aging (IANA) proposed the FRAIL scale [95]. This scale combines elements of the frailty phenotype with the presence of comorbid diseases. It comprises 5 domains: fatigue (defined as having less energy than in the past), resistance (defined as the inability to climb stairs), ambulation (defined as the inability to walk one block), number of illnesses (defined as more than five concurrent illnesses) 
and loss of weight (more than $5 \%$ in 1 year). As with the frailty phenotype of Fried et al., a person is classified as frail if at least three criteria are present, while those with one or two criteria are pre-frail and those with no criteria robust. To our knowledge, the predictive value for adverse outcomes of the FRAIL scale has been validated in only one prospective cohort study, in which frailty was associated with disability and mortality [72].

\section{The Need for a Consensus Definition of Frailty}

Thus, multiple operational definitions to measure frailty have been proposed, but one consensus definition is still lacking. There is, however, a need for such a consensus definition in research and clinical practice, because, even though the different frailty models have been able to identify vulnerable individuals to stressors, they do not identify the same individuals as being frail [96-98]. Moreover, a consensus definition might enhance the development of risk assessments strategies and new therapies, as was the case with the consensus definition of osteoporosis [99]. Rockwood et al. [100] and Gobbens et al. [101] have proposed several criteria that a consensus definition of frailty should meet. The first of their criteria is that the measure should include multiple domains of functioning, and not only the physical domain, as is the case in the frailty definition of Fried et al. [54]. Secondly, the definition should consider frailty as a dynamic process and should therefore be able to distinguish several degrees of frailty. This criterion is met by the frailty definition of Fried et al. [54] by which individuals were classified as frail, pre-frail, or robust. The third criterion is that a consensus definition should have strong validity. Because there is no gold standard against which a consensus definition of frailty can be validated, the definition should have great predictive validity, which is the ability to predict adverse outcomes such as institutionalization, hospitalization and mortality. As discussed, the definitions of Fried et al. [54] and Rockwood et al. [91] were both predictive of a range of adverse outcomes in several trials, while the FRAIL scale has only been validated in one study [72]. Furthermore, Rockwood et al. [100] propose that there should be a correlation between the frailty measure and age, comorbidity and disability, which should, however, according to Gobbens et al. [101], not be part of the definition. Gobbens et al. argue that, as discussed before, frailty, comorbidity and disability may interact, but are three distinct entities. Similarly, ageing is not synonymous to developing frailty, although the prevalence of frailty increases with ageing. The frailty index of Rockwood [91] and the FRAIL scale [95] incorporate disability and/or comorbidity and thus do not meet this fourth criterion of a consensus definition.
Finally, a consensus operational definition should include components on which interventions can be focused [100, 101].

So far, there is no definition that meets all these criteria. Developing and validating such a definition that can be used in research and clinical practice is one of the goals in future research on frailty.

Epidemiology of Frailty

The prevalence of frailty depends on the population studied and on the operational definition used. Prevalence estimates vary greatly as study populations are heterogeneous and several definitions including different component criteria have been used [102]. Regardless of the criteria used, the prevalence increases with age, such that in the age group between 50 and 65 years less than $5 \%$ are defined as frail [85], while this \%age can be over $25 \%$ in people above 90 [54, 64]. In addition, the prevalence of frailty is higher in women than in men for reasons that are not clear $[54,85]$.

\section{Prevention and Treatment of Frailty}

The development of frailty is a dynamic process. In a prospective study investigating the spontaneous evolution of frailty in persons of 70 years and over, transition between the consecutive stages of frailty (robust, pre-frail, frail) was not exceptional and progressed, as expected, toward higher frailty. A reversed evolution of frail to robust was uncommon [103]. Nevertheless, frailty is to some extent preventable. A number of therapeutic approaches have been used; their aim being to slow down the process or at least to avoid the adverse clinical consequences of frailty. In the following sections, these therapeutic approaches are discussed; including those targeting primarily the musculoskeletal system and those including other systems. These therapies target the mechanisms that contribute to the development of (musculoskeletal) frailty, which have been discussed before.

\section{Therapeutic Approaches to Musculoskeletal Frailty (Table 2)}

A recent meta-analysis showed that exercise therapy in frail elderly had a positive impact on some physical determinants (such as body composition and muscle function) and functional ability (such as mobility and balance). A combined exercise program of long duration ( $\geq 5$ months) performed three times a week for 30-45 min had superior outcomes [104]. This beneficial effect of physical exercises on frailty may be explained by its effect on muscle and bone. 
Numerous studies have indeed shown that, even in the elderly, progressive resistance training is an effective intervention for sarcopenia [105]. That also elderly may benefit from resistance training is clear from a randomized placebo-controlled trial of Fiatarone et al., in which institutionalized persons with a mean age of 87 years undertook a 10 -week progressive resistance training program. The training program, that consisted of three times a week three series of eight repetitions with a resistance of $80 \%$ of one repetition maximum (RM, the maximum weight that can be lifted), significantly improved muscle strength, walking speed and physical activity. Also muscle power increased significantly more in the exercisers as compared with the controls, although it increased less than muscle strength [40]. To improve muscle power, high-velocity progressive resistance training may be better than the traditional (lowvelocity) progressive resistance training [106]. Change in muscle mass was not significantly different between the exercise and control group [40]. An alternative of resistance training is whole-body vibration training, during which the patient stands on a platform that generates vertical sinusoidal vibrations. These mechanical stimuli activate the muscle spindles, which activates the alpha motor neurons and initiates muscle contraction [107]. Similar to resistance training, vibration training enlarges muscle strength, but also muscle mass [108].

In addition, physical exercise training may also have an effect on bone, even in the elderly. A recent Cochrane review about the effectiveness of exercise in postmenopausal women showed a relatively small, but statistically significant effect of physical activity on bone mineral density (BMD). The most effective interventions were a combined exercise program (progressive resistance training and weight bearing exercises) for lumbar spine BMD and progressive resistance training for femoral neck BMD [109]. Also in older men, resistance training increased BMD at the hip, but this increase was, contrary to women, not greater than in active controls [110]. Whole-body vibration had positive effects on BMD in some studies [108], but in a recent meta-analysis, no important effect was observed [111].

Androgen therapy has also been suggested in the management of musculoskeletal frailty. Testosterone replacement, which may improve muscle mass and strength in older men [112], may also have a beneficial effect in frail elderly [113]. For example, in a randomized clinical trial, men of 65 years and older with a reduced testosterone level and at least one criterion of frailty according to Fried et al. [54], were treated with testosterone for 6 months. Testosterone replacement increased muscle mass and strength, and-in a subset of men who were older ( $\geq 75$ years) or who met at least two frailty criteria-physical performance improved as well [114]. In a study in older men with mobility limitation, testosterone administration was associated with an improvement in muscle strength and power [115]. However, in another study in frail men, testosterone replacement for 12-24 months did increase muscle mass, but not muscle strength or physical performance [116]. It remains to be established whether, by its effect on muscle, testosterone may decrease the risk of fractures in frail elderly through a reduced propensity of falls.

What also needs to be clarified is to what extent testosterone decreases fracture risk of frail elderly through an effect on bone. Indeed, whether androgens have an additional beneficial effect on bone remains a matter of debate [117]. Although testosterone replacement is indicated for men with symptomatic hypogonadism at all ages, its benefit is more controversial in elderly men. Testosterone replacement significantly improved BMD in elderly patients with the lowest pretreatment testosterone levels $(<200 \mathrm{ng} / \mathrm{dL}$ or $6.94 \mathrm{nmol} / \mathrm{L})$, while no to minor effects were observed in men with low-normal or borderline low testosterone concentrations [118]. Low testosterone and symptoms and signs consistent with hypogonadism become increasingly prevalent with ageing, but are also less specific [119]. Osteoporosis for example may only be partly related to the decline in testosterone. Therefore, testosterone replacement is not indicated in elderly men with osteoporosis and borderline low levels of testosterone, but should be restricted to those men with repeated documented serum testosterone $<200 \mathrm{ng} / \mathrm{dL}$ and consistent signs and symptoms of hypogonadism [117]. What should be mentioned is that because these trials have been small and of short duration, no firm conclusion on fracture risk reduction is possible at this stage.

In conclusion, more studies are required to provide further evidence for the effect of testosterone on muscle and bone in frail elderly. The potential adverse consequences of testosterone, including prostate carcinoma and cardiovascular risks, need also to be considered [120]. In a meta-analysis about the adverse effects of testosterone therapy in adult men, there was no significant effect on prostate and cardiovascular outcomes [121]. However, because another meta-analysis did find a significantly higher risk of prostate events [122], the endocrine society still refers to the possible higher risk of prostate events and the "unknown long-term risks of testosterone" [123].

Because sarcopenia and frailty have been linked with vitamin D deficiency [75], supplementation with vitamin D may be another therapy of musculoskeletal frailty. Although the association between vitamin D supplementation and an improvement in physical performance remains controversial [124], there is increasing evidence that a daily dose of $700-1,000$ international units (IU) vitamin D significantly increases muscle strength in elderly persons with vitamin D deficiency [125]. Also the risk of falls of elderly is reduced when, with supplementation therapy, a serum vitamin D 
level of $>60 \mathrm{nmol} / \mathrm{L}$ is achieved [126]. The effect of vitamin D may be partly related to its effect on muscle tissue via a vitamin D receptor present in muscle cells [127]. Furthermore, vitamin D receptors are expressed in many other cell types, through which vitamin D has pleiotropic effects, including an effect on neural function, which may also contribute to its effect on muscle function and prevention of falls $[128,129]$. In combination with a daily dose of 1,000-1,200 mg of elementary calcium, vitamin D also reverses the age-associated secondary hyperparathyroidism. This does not only counteract the negative effect of PTH on muscle, but also that on bone, with a resultant beneficial effect on BMD [130]. The combination of a reduced propensity to falls and an increased bone mass may decrease fracture risk in frail elderly treated with calcium and vitamin D supplements [131].

Growth hormone (GH), which has been used successfully in patients suffering from GH deficiency, is another potential therapy of frailty. There is, however, to our knowledge only one study looking at the impact of growth hormone in frail elderly. This study showed an increase in type II muscle fibers [132]. Studies on the use of growth hormone during normal ageing showed an increase in fatfree mass, but this was not associated with functional improvement [133, 134]. Moreover, elderly people are susceptible to the adverse effects of growth hormones [135]. Therefore, their use is not recommended in this population. An alternative therapy may be treatment with growth hormone secretagogues (GHS), which regulate the secretion of GH and usually have fewer adverse effects. Oral GHS have been developed that significantly increased muscle mass [136, 137] and in one trial also physical performance improved [136].

Data looking at the effect of nutritional supplements (including protein supplementation) in elderly persons suggest that, while such supplements may increase body weight, there is no evidence of any effect on muscle mass and strength or functional deficits [40, 138].

Frail elderly diagnosed with osteoporosis need to embark on antiresorptive or anabolic therapy, as even in frail older people with advanced osteoporosis and (hip) fractures, osteoporosis medication protects against recurrent fractures and improves survival $[130,139]$. The reduction in mortality is partly due to a reduction in secondary fractures and partly to less secondary complications such as cardiovascular events and infections [140]. It is not surprising that frail elderly people benefit most from osteoporosis treatment. Antiresorptive or anabolic therapy will, independent of age, protect against fractures, and this protection increases with age in absolute terms: a comparable relative risk reduction (for instance a decrease in the risk of hip fractures by $40 \%$ ) will render a larger absolute risk reduction in elderly people, because older people have a higher baseline fracture risk
[139]. A recent study with strontium ranelate confirmed that the number of subjects needed to treat to prevent one fracture (NNT) was lowest among frail older people who have the highest fracture risk [53]. Similarly, in frail elderly, osteoporosis medication will have a greater impact on the secondary complications of fractures such as disability, institutionalization and mortality. This is because frail persons have a higher baseline risk for adverse consequences of stressors such as fractures [54, 141-143]. The same holds true for the obtainable difference in quality of life, which is much higher in very old people because the loss of quality of life after a fracture is much larger for them [144]. Thus, for every avoided fracture, elderly people have a larger gain in quality of life.

Several new therapeutic interventions to improve musculoskeletal frailty are under development or being tested in clinical trials. We will briefly discuss the most important ones and refer to references $[145,146]$ for an extensive overview.

Nonsteroidal selective androgen receptor modulators (SARMs) are thought to have the benefits of testosterone on muscle and bone, but not the adverse effects on prostate and cardiovascular outcomes. Studies in frail persons are still lacking, but in healthy elderly SARMs improved fatfree mass and muscle power [113].

The therapeutic potential of antagonists of myostatin, an inhibitor of muscle differentiation and growth, is currently being tested in phase I and II trials. Antibody-directed inhibition of myostatin might be an effective treatment of sarcopenia by inhibiting protein degradation and/or apoptosis [146].

There is some preliminary evidence that ursolic acid and eicosapentaenoic acid (EPA, an omega-3 polyunsaturated fatty acid with anti-inflammatory properties) might be effective therapeutic agents for sarcopenia, but more research is needed to confirm this [146].

In addition to the use in cardiovascular prevention, angiotensin-converting enzyme (ACE) inhibitors have recently been suggested to have a beneficial effect on muscle function in frail elderly [147]. However, it remains to be established whether this has to be attributed to the cardiovascular effects of ACE inhibitors, because frail individuals often have cardiovascular problems [146].

Another promising therapy is IGF-1, of which lower levels have been linked with prevalent frailty. IGF-1 is secreted in most tissues, including the liver (circulating IGF-1, cIGF-1) and the muscles (muscle-specific IGF-I, mIGF-1) under the influence of growth hormone. mIGF-1 is also synthesized in muscles in response to exercise. In animal models and muscle cell cultures, mIGF-1 infusion stimulated muscle hypertrophy [148]. More research is needed to confirm this result in humans and to determine the benefit of m-IGF-1 administration in frail elderly. 
Table 2 Therapeutic approaches to musculoskeletal frailty

\begin{tabular}{|c|c|c|}
\hline Approach & Advantages & Disadvantages \\
\hline \multicolumn{3}{|l|}{ Physical exercise } \\
\hline $\begin{array}{l}\text { Progressive resistance } \\
\text { training }\end{array}$ & $\begin{array}{l}\text { Increase in muscle strength and power [40] } \\
\text { Increase in physical performance and activity [40] } \\
\text { Increase in BMD [109] }\end{array}$ & \\
\hline $\begin{array}{l}\text { Whole-body vibration } \\
\text { training }\end{array}$ & $\begin{array}{l}\text { Increase in muscle mass [108] } \\
\text { Increase in muscle strength [108] } \\
\text { Increase in BMD in some studies [108] }\end{array}$ & \\
\hline Testosterone $(\mathrm{T})$ & $\begin{array}{l}\text { Increase in muscle mass }[114,158] \\
\text { Increase in muscle strength and performance in } \\
\text { some trials }[114,115] \\
\text { Increase in BMD when } \mathrm{T}<200 \mathrm{ng} / \mathrm{dL} \text { and signs } \\
\text { of hypogonadism [118] }\end{array}$ & $\begin{array}{l}\text { Possible higher risk of prostate events [123] } \\
\text { Possible higher risk of cardiovascular events [120] }\end{array}$ \\
\hline $\begin{array}{l}\text { Vitamin D } \\
\quad(700-1,000 \mathrm{IU})\end{array}$ & $\begin{array}{l}\text { Increase in muscle strength in vitamin D deficient } \\
\text { elderly [125] } \\
\text { Increase in physical performance (controversial) } \\
\text { [124] } \\
\text { Decrease in fall risk when achieving vitamin D } \\
\text { level }>60 \mathrm{nmol} / \mathrm{L}[126] \\
\text { Increase in BMD when combined with } \\
1000-1200 \mathrm{mg} \text { calcium [130] }\end{array}$ & Increased risk of falls/fractures with annual high-dose [159] \\
\hline Growth hormone & Increase in muscle mass $[133,134]$ & $\begin{array}{l}\text { No functional improvement }[133,134] \\
\text { Adverse effects (soft tissue edema, arthralgias, gynecomastia } \\
\text { carpal tunnel syndrome) [135] }\end{array}$ \\
\hline $\begin{array}{l}\text { Growth hormone } \\
\text { secretagogue }\end{array}$ & $\begin{array}{l}\text { Increase in muscle mass }[136,137] \\
\text { Increase in physical performance in some trials } \\
\text { [136] } \\
\text { Generally well tolerated [137] }\end{array}$ & \\
\hline $\begin{array}{l}\text { High-protein diet } \\
(1.2-1.5 \mathrm{~g} / \mathrm{kg})\end{array}$ & Increase in body weight $[40,138]$ & No functional improvement $[40,138]$ \\
\hline $\begin{array}{l}\text { Antiresorptive or } \\
\text { anabolic therapy }\end{array}$ & $\begin{array}{l}\text { Reduction of the incidence of secondary fractures } \\
{[130,139]} \\
\text { Improved survival after a fracture [130] }\end{array}$ & \\
\hline
\end{tabular}

Because also the age-associated low-grade inflammatory profile with elevated levels of cytokines contributes to the development of frailty, drugs that downregulate the cytokine system are potential therapeutic agents that need to be investigated further [145].

Finally, also high intake of carotenoids, which act as antioxidants, may be a strategy to treat frailty, because, as discussed, the production of ROS might lead to frailty. In the WHAS trial, subjects in the highest quartile of carotenoid levels were at lower risk of diminished muscle strength, but interventional trials in frail elderly are lacking [149].

\section{Global Approach}

Because frailty goes beyond the musculoskeletal component, the syndrome requires a more global medical approach that also takes into account the vulnerability of the nonmusculoskeletal organ systems. The unfavorable prognosis for older patients with hip fractures has been discussed as a typical example of an organism-wide, agerelated frailty that, even years after the fracture, predisposes for functional deficits, comorbidity and mortality. Therefore, hip fracture patients would benefit from a broad approach in which geriatric after-care is offered, in addition to surgery, revalidation, prevention of fractures and osteoporosis medication. Hip fracture patients, and more generally, frail elderly people, are good candidates for a comprehensive geriatric assessment, by which functional deficits and comorbidity are mapped accurately, forming the basis for an individual treatment plan and medical follow-up. The added value of such treatment has been proven indisputably [150, 151].

In our ageing population, it will be a major challenge to offer adapted care to frail elderly, in order to protect their 
quality of life and independence, and to prevent disease complications at advanced age. The first step to achieve this, is to recognize these frail elderly, by focusing on functional deficits and comorbidity. As a comprehensive geriatric assessment allows such a systematic screening for frail old people in general medical practice and hospitals, it is central in geriatrics.

\section{Prevention of Frailty}

Physical exercise therapy may not only be important in the treatment of frailty, but also in the prevention. Because frailty results from reaching a threshold of decline across multiple organ systems, an approach to prevent frailty is supposed to act on multiple systems. Physical activity has been linked with an increase in muscle mass and muscle strength, which was discussed before, and may also improve insulin sensitivity [152], modulate inflammation [153] and hormonal function [154, 155], and have cardiovascular effects [156]. Whether an increase in physical activity indeed prevents frailty and disability is currently being investigated by Fried et al. in the Baltimore Experience Corps Study [157].

\section{Conclusion}

Frail older people typically have reduced reserves in different physiological systems, which makes them susceptible to functional deficits and vulnerable to comorbidity, and causes an increased risk of institutionalization, hospitalization and death. In order to alleviate these negative consequences and, if possible, to prevent them, it is essential to recognize frailty as early as possible in an ageing population, and to offer the appropriate care. Frailty requires a global geriatric assessment that incorporates functional deficits and comorbidity, and offers treatment and follow-up tailored to the needs of the individual elderly person.

Acknowledgments S. Boonen is senior clinical investigator of the Fund for Scientific Research (FWO-Vlaanderen) and holder of the Leuven University Chair in Gerontology and Geriatrics. This work was supported by Grant G.0488.08 from the Fund for Scientific Research (FWO-Vlaanderen) to S. Boonen and research grants OT-05-53 and OT-09-035 from the KU Leuven to D. Vanderschueren. D. Vanderschueren is a senior clinical investigator of the Leuven University Hospital Clinical Research Fund.

\section{References}

1. Walston J, Hadley EC, Ferrucci L, Guralnik JM, Newman AB, Studenski SA, Ershler WB, Harris T, Fried LP (2006) Research agenda for frailty in older adults: toward a better understanding of physiology and etiology: summary from the American geriatrics society/national institute on aging research conference on frailty in older adults. J Am Geriatr Soc 54:991-1001

2. Rosenberg IH (1989) Summary comments. Am J Clin Nutr 50:3

3. Baumgartner RN, Koehler KM, Gallagher D, Romero L, Heymsfield SB, Ross RR, Garry PJ, Lindeman RD (1998) Epidemiology of sarcopenia among the elderly in New Mexico. Am J Epidemiol 147:755-763

4. Janssen I (2006) Influence of sarcopenia on the development of physical disability: the cardiovascular health study. J Am Geriatr Soc 54:56-62

5. Visser M, Goodpaster BH, Kritchevsky SB, Newman AB, Nevitt M, Rubin SM, Simonsick EM, Harris TB (2005) Muscle mass, muscle strength, and muscle fat infiltration as predictors of incident mobility limitations in well-functioning older persons. J Gerontol A Biol Sci Med Sci 60:324-333

6. Szulc P, Beck TJ, Marchand F, Delmas PD (2005) Low skeletal muscle mass is associated with poor structural parameters of bone and impaired balance in elderly men - the MINOS study. J Bone Miner Res 20:721-729

7. Landi F, Liperoti R, Russo A, Giovannini S, Tosato M, Capoluongo E, Bernabei R, Onder G (2012) Sarcopenia as a risk factor for falls in elderly individuals: results from the ilSIRENTE study. Clin Nutr 96:1150-1163

8. Lang TF, Cauley J, Tylavsky F, Bauer D, Cummings S, Harris T (2010) Computed tomography measurements of thigh muscle cross-sectional area and attenuation coefficient predict hip fracture: the health, aging and body composition study. J Bone Miner Res 25:513-519

9. Landi F, Liperoti R, Fusco D, Mastropaolo S, Quattrociocchi D, Proia A, Tosato M, Bernabei R, Onder G (2012) Sarcopenia and mortality among older nursing home residents. J Am Med Dir Assoc 13:121-126

10. Lang T, Streeper T, Cawthon P, Baldwin K, Taaffe DR, Harris TB (2010) Sarcopenia: etiology, clinical consequences, intervention, and assessment. Osteoporos Int 21:543-559

11. Gallagher D, Visser M, De Meersman RE, Sepulveda D, Baumgartner RN, Pierson RN, Harris T, Heymsfield SB (1997) Appendicular skeletal muscle mass: effects of age, gender, and ethnicity. J Appl Physiol 83:229-239

12. Doherty TJ (2003) Invited review: aging and sarcopenia. J Appl Physiol 95:1717-1727

13. Janssen I, Heymsfield SB, Wang ZM, Ross R (2000) Skeletal muscle mass and distribution in 468 men and women aged 18-88 yr. J Appl Physiol 89:81-88

14. Beyer I, Njemini R, Bautmans I, Demanet C, Bergmann P, Mets $T$ (2012) Inflammation-related muscle weakness and fatigue in geriatric patients. Exp Gerontol 47:52-59

15. Cesari M, Kritchevsky SB, Baumgartner RN, Atkinson HH, Penninx BW, Lenchik L, Palla SL, Ambrosius WT, Tracy RP, Pahor M (2005) Sarcopenia, obesity, and inflammation-results from the trial of angiotensin converting enzyme inhibition and novel cardiovascular risk factors study. Am J Clin Nutr 82: 428-434

16. Szulc P, Duboeuf F, Marchand F, Delmas PD (2004) Hormonal and lifestyle determinants of appendicular skeletal muscle mass in men: the MINOS study. Am J Clin Nutr 80:496-503

17. Araujo AB, Travison TG, Bhasin S, Esche GR, Williams RE, Clark RV, McKinlay JB (2008) Association between testosterone and estradiol and age-related decline in physical function in a diverse sample of men. J Am Geriatr Soc 56:2000-2008

18. Visser M, Deeg DJ, Lips P (2003) Low vitamin D and high parathyroid hormone levels as determinants of loss of muscle strength and muscle mass (sarcopenia): the longitudinal aging study Amsterdam. J Clin Endocrinol Metab 88:5766-5772

19. Perrini S, Laviola L, Carreira MC, Cignarelli A, Natalicchio A, Giorgino F (2010) The GH/IGF1 axis and signaling pathways in 
the muscle and bone: mechanisms underlying age-related skeletal muscle wasting and osteoporosis. J Endocrinol 205:201-210

20. Abbatecola AM, Paolisso G, Fattoretti P, Evans WJ, Fiore V, Dicioccio L, Lattanzio F (2011) Discovering pathways of sarcopenia in older adults: a role for insulin resistance on mitochondria dysfunction. J Nutr Health Aging 15:890-895

21. Abbatecola AM, Paolisso G (2008) Is there a relationship between insulin resistance and frailty syndrome? Curr Pharm Des 14:405-410

22. Marzetti E, Leeuwenburgh C (2006) Skeletal muscle apoptosis, sarcopenia and frailty at old age. Exp Gerontol 41:1234-1238

23. Morley JE, Anker SD, Evans WJ (2009) Cachexia and aging: an update based on the fourth international cachexia meeting. J Nutr Health Aging 13:47-55

24. Clark BC, Manini TM (2008) Sarcopenia =/= dynapenia. J Gerontol A Biol Sci Med Sci 63:829-834

25. Manini TM, Clark BC (2012) Dynapenia and aging: an update. J Gerontol A Biol Sci Med Sci 67:28-40

26. Hughes VA, Frontera WR, Wood M, Evans WJ, Dallal GE, Roubenoff R, Singh MAF (2001) Longitudinal muscle strength changes in older adults: influence of muscle mass, physical activity, and health. J Gerontol A Biol Sci Med Sci 56:B209B217

27. Cruz-Jentoft AJ, Baeyens JP, Bauer JM, Boirie Y, Cederholm T, Landi F, Martin FC, Michel JP, Rolland Y, Schneider SM, Topinkova E, Vandewoude M, Zamboni M (2010) Sarcopenia: European consensus on definition and diagnosis: report of the European working group on sarcopenia in older People. Age Ageing 39:412-423

28. Kyle UG, Genton L, Karsegard L, Slosman DO, Pichard C (2001) Single prediction equation for bioelectrical impedance analysis in adults aged 20-94 years. Nutrition 17:248-253

29. Fielding RA, Vellas B, Evans WJ, Bhasin S, Morley JE, Newman AB, van Kan GA, Andrieu S, Bauer J, Breuille D, Cederholm T, Chandler J, De Meynard C, Donini L, Harris T, Kannt A, Guibert FK, Onder G, Papanicolaou D, Rolland Y, Rooks D, Sieber C, Souhami E, Verlaan S, Zamboni M (2011) Sarcopenia: an undiagnosed condition in older adults. Current consensus definition: prevalence, etiology, and consequences. International working group on sarcopenia. J Am Med Dir Assoc 12:249-256

30. Muscaritoli M, Anker SD, Argiles J, Aversa Z, Bauer JM, Biolo G, Boirie Y, Bosaeus I, Cederholm T, Costelli P, Fearon KC, Laviano A, Maggio M, Fanelli FR, Schneider SM, Schols A, Sieber CC (2010) Consensus definition of sarcopenia, cachexia and pre-cachexia: joint document elaborated by special interest groups (SIG) "cachexia-anorexia in chronic wasting diseases" and "nutrition in geriatrics". Clin Nutr 29:154-159

31. Morley JE, Abbatecola AM, Argiles JM, Baracos V, Bauer J, Bhasin S, Cederholm T, Coats AJ, Cummings SR, Evans WJ, Fearon K, Ferrucci L, Fielding RA, Guralnik JM, Harris TB, Inui A, Kalantar-Zadeh K, Kirwan BA, Mantovani G, Muscaritoli M, Newman AB, Rossi-Fanelli F, Rosano GM, Roubenoff R, Schambelan M, Sokol GH, Storer TW, Vellas B, von Haehling S, Yeh SS, Anker SD (2011) Sarcopenia with limited mobility: an international consensus. J Am Med Dir Assoc 12:403-409

32. Newman AB, Kupelian V, Visser M, Simonsick EM, Goodpaster BH, Kritchevsky SB, Tylavsky FA, Rubin SM, Harris TB (2006) Strength, but not muscle mass, is associated with mortality in the health, aging and body composition study cohort. J Gerontol A Biol Sci Med Sci 61:72-77

33. Puthoff ML, Nielsen DH (2007) Relationships among impairments in lower-extremity strength and power, functional limitations, and disability in older adults. Phys Ther 87:1334-1347

34. Foldvari M, Clark M, Laviolette LC, Bernstein MA, Kaliton D, Castaneda C, Pu CT, Hausdorff JM, Fielding RA, Singh MA
(2000) Association of muscle power with functional status in community-dwelling elderly women. J Gerontol A Biol Sci Med Sci 55:M192-M199

35. Skelton DA, Greig CA, Davies JM, Young A (1994) Strength, power and related functional ability of healthy people aged 65-89 years. Age Ageing 23:371-377

36. Bean JF, Kiely DK, Herman S, Leveille SG, Mizer K, Frontera WR, Fielding RA (2002) The relationship between leg power and physical performance in mobility-limited older people. J Am Geriatr Soc 50:461-467

37. Bean JF, Leveille SG, Kiely DK, Bandinelli S, Guralnik JM, Ferrucci L (2003) A comparison of leg power and leg strength within the InCHIANTI study: which influences mobility more? J Gerontol A Biol Sci Med Sci 58:728-733

38. Lauretani F, Russo CR, Bandinelli S, Bartali B, Cavazzini C, Di Iorio A, Corsi AM, Rantanen T, Guralnik JM, Ferrucci L (2003) Age-associated changes in skeletal muscles and their effect on mobility: an operational diagnosis of sarcopenia. J Appl Physiol 95:1851-1860

39. Marsh AP, Miller ME, Saikin AM, Rejeski WJ, Hu N, Lauretani F, Bandinelli S, Guralnik JM, Ferrucci L (2006) Lower extremity strength and power are associated with 400-meter walk time in older adults: the InCHIANTI study. J Gerontol A Biol Sci Med Sci 61:1186-1193

40. Fiatarone MA, O'Neill EF, Ryan ND, Clements KM, Solares GR, Nelson ME, Roberts SB, Kehayias JJ, Lipsitz LA, Evans WJ (1994) Exercise training and nutritional supplementation for physical frailty in very elderly people. $\mathrm{N}$ Engl $\mathrm{J}$ Med 330: 1769-1775

41. Bean JF, Kiely DK, LaRose S, O’Neill E, Goldstein R, Frontera WR (2009) Increased velocity exercise specific to task training versus the National institute on aging's strength training program: changes in limb power and mobility. J Gerontol A Biol Sci Med Sci 64:983-991

42. Hedayati KK, Dittmar M (2010) Prevalence of sarcopenia among older community-dwelling people with normal health and nutritional state. Ecol Food Nutr 49:9

43. Iannuzzi-Sucich M, Prestwood KM, Kenny AM (2002) Prevalence of sarcopenia and predictors of skeletal muscle mass in healthy, older men and women. J Gerontol A Biol Sci Med Sci 57:M772-M777

44. Baumgartner RN (2000) Body composition in healthy aging. Ann N Y Acad Sci 904:437-448

45. Stenholm S, Harris TB, Rantanen T, Visser M, Kritchevsky SB, Ferrucci L (2008) Sarcopenic obesity: definition, cause and consequences. Curr Opin Clin Nutr Metab Care 11:693-700

46. Stenholm S, Rantanen T, Heliovaara M, Koskinen S (2008) The mediating role of $\mathrm{C}$-reactive protein and handgrip strength between obesity and walking limitation. J Am Geriatr Soc 56:462-469

47. Rantanen T, Harris T, Leveille SG, Visser M, Foley D, Masaki K, Guralnik JM (2000) Muscle strength and body mass index as long-term predictors of mortality in initially healthy men. J Gerontol A Biol Sci Med Sci 55:M168-M173

48. National Institute on Aging Baltimore (1958-1998) Longitudinal study of aging. Selected findings from 1978-1998. http:// www.grc.nia.nih.gov/branches/blsa/blsafindings.pdf. Accessed 1 Sep 2005

49. Gondo Y, Hirose N, Arai Y, Inagaki H, Masui Y, Yamamura K, Shimizu K, Takayama M, Ebihara Y, Nakazawa S, Kitagawa K (2006) Functional status of centenarians in Tokyo, Japan: developing better phenotypes of exceptional longevity. J Gerontol A Biol Sci Med Sci 61:305-310

50. Woods NF, LaCroix AZ, Gray SL, Aragaki A, Cochrane BB, Brunner RL, Masaki K, Murray A, Newman AB (2005) Frailty: emergence and consequences in women aged 65 and older in the 
Women's health initiative observational study. J Am Geriatr Soc 53:1321-1330

51. Ensrud KE, Ewing SK, Cawthon PM, Fink HA, Taylor BC, Cauley JA, Dam TT, Marshall LM, Orwoll ES, Cummings SR (2009) A comparison of frailty indexes for the prediction of falls, disability, fractures, and mortality in older men. J Am Geriatr Soc 57:492-498

52. Ensrud KE, Ewing SK, Taylor BC, Fink HA, Cawthon PM, Stone KL, Hillier TA, Cauley JA, Hochberg MC, Rodondi N, Tracy JK, Cummings SR (2008) Comparison of 2 frailty indexes for prediction of falls, disability, fractures, and death in older women. Arch Intern Med 168:382-389

53. Rolland Y, Van Kan GA, Gillette-Guyonnet S, Roux C, Boonen S, Vellas B (2011) Strontium ranelate and risk of vertebral fractures in frail osteoporotic women. Bone 48:332-338

54. Fried LP, Tangen CM, Walston J, Newman AB, Hirsch C, Gottdiener J, Seeman T, Tracy R, Kop WJ, Burke G, McBurnie MA (2001) Frailty in older adults: evidence for a phenotype. J Gerontol A Biol Sci Med Sci 56:M146-M156

55. Bandeen-Roche K, Xue QL, Ferrucci L, Walston J, Guralnik JM, Chaves P, Zeger SL, Fried LP (2006) Phenotype of frailty: characterization in the women's health and aging studies. J Gerontol A Biol Sci Med Sci 61:262-266

56. Rockwood K, Mitnitski A, Song X, Steen B, Skoog I (2006) Long-term risks of death and institutionalization of elderly people in relation to deficit accumulation at age 70 . J Am Geriatr Soc 54:975-979

57. Fried LP, Ferrucci L, Darer J, Williamson JD, Anderson G (2004) Untangling the concepts of disability, frailty, and comorbidity: implications for improved targeting and care. J Gerontol A Biol Sci Med Sci 59:255-263

58. Fried LP, Darer J, Walston J (2003) Frailty. Springer-Verlag, New York

59. Binkley N, Buehring B (2009) Beyond FRAX: it's time to consider "sarco-osteopenia". J Clin Densitom 12:413-416

60. Bortz WM 2nd (2002) A conceptual framework of frailty: a review. J Gerontol A Biol Sci Med Sci 57:M283-M288

61. Haentjens P, Magaziner J, Colon-Emeric CS, Vanderschueren D, Milisen K, Velkeniers B, Boonen S (2010) Meta-analysis: excess mortality after hip fracture among older women and men. Ann Intern Med 152:380-390

62. Boonen S, Autier P, Barette M, Vanderschueren D, Lips P, Haentjens P (2004) Functional outcome and quality of life following hip fracture in elderly women: a prospective controlled study. Osteoporos Int 15:87-94

63. Kanapuru B, Ershler WB (2009) Inflammation, coagulation, and the pathway to frailty. Am J Med 122:605-613

64. Walston J, McBurnie MA, Newman A, Tracy RP, Kop WJ, Hirsch CH, Gottdiener J, Fried LP (2002) Frailty and activation of the inflammation and coagulation systems with and without clinical comorbidities: results from the cardiovascular health study. Arch Intern Med 162:2333-2341

65. Barzilay JI, Blaum C, Moore T, Xue QL, Hirsch CH, Walston JD, Fried LP (2007) Insulin resistance and inflammation as precursors of frailty: the cardiovascular health study. Arch Intern Med 167:635-641

66. Reiner AP, Aragaki AK, Gray SL, Wactawski-Wende J, Cauley JA, Cochrane BB, Kooperberg CL, Woods NF, LaCroix AZ (2009) Inflammation and thrombosis biomarkers and incident frailty in postmenopausal women. Am J Med 122: 947-954

67. Wu IC, Shiesh SC, Kuo PH, Lin XZ (2009) High oxidative stress is correlated with frailty in elderly Chinese. J Am Geriatr Soc 57:1666-1671

68. Mulero J, Zafrilla P, Martinez-Cacha A (2011) Oxidative stress, frailty and cognitive decline. J Nutr Health Aging 15:756-760
69. Ho YY, Matteini AM, Beamer B, Fried L, Xue QL, Arking DE, Chakravarti A, Fallin MD, Walston J (2011) Exploring biologically relevant pathways in frailty. J Gerontol A Biol Sci Med Sci 66:975-979

70. Mohr BA, Bhasin S, Kupelian V, Araujo AB, O'Donnell AB, McKinlay JB (2007) Testosterone, sex hormone-binding globulin, and frailty in older men. J Am Geriatr Soc 55:548-555

71. Tajar A, O'Connell MD, Mitnitski AB, O'Neill TW, Searle SD, Huhtaniemi IT, Finn JD, Bartfai G, Boonen S, Casanueva FF, Forti G, Giwercman A, Han TS, Kula K, Labrie F, Lean ME, Pendleton N, Punab M, Silman AJ, Vanderschueren D, Rockwood K, Wu FC (2011) Frailty in relation to variations in hormone levels of the hypothalamic-pituitary-testicular axis in older men: results from the European male aging study. J Am Geriatr Soc 59:814-821

72. Hyde Z, Flicker L, Almeida OP, Hankey GJ, McCaul KA, Chubb SA, Yeap BB (2010) Low free testosterone predicts frailty in older men: the health in men study. J Clin Endocrinol Metab 95:3165-3172

73. Travison TG, Nguyen AH, Naganathan V, Stanaway FF, Blyth FM, Cumming RG, Le Couteur DG, Sambrook PN, Handelsman DJ (2011) Changes in reproductive hormone concentrations predict the prevalence and progression of the frailty syndrome in older men: the concord health and ageing in men project. J Clin Endocrinol Metab 96:2464-2474

74. Cawthon PM, Ensrud KE, Laughlin GA, Cauley JA, Dam TT, Barrett-Connor E, Fink HA, Hoffman AR, Lau E, Lane NE, Stefanick ML, Cummings SR, Orwoll ES (2009) Sex hormones and frailty in older men: the osteoporotic fractures in men (MrOS) study. J Clin Endocrinol Metab 94:3806-3815

75. Perez-Lopez FR, Chedraui P, Fernandez-Alonso AM (2011) Vitamin D and aging: beyond calcium and bone metabolism. Maturitas 69:27-36

76. Ensrud KE, Ewing SK, Fredman L, Hochberg MC, Cauley JA, Hillier TA, Cummings SR, Yaffe K, Cawthon PM (2010) Circulating 25-hydroxyvitamin D levels and frailty status in older women. J Clin Endocrinol Metab 95:5266-5273

77. Ensrud KE, Blackwell TL, Cauley JA, Cummings SR, BarrettConnor E, Dam TT, Hoffman AR, Shikany JM, Lane NE, Stefanick ML, Orwoll ES, Cawthon PM (2011) Circulating 25-hydroxyvitamin D levels and frailty in older men: the osteoporotic fractures in men study. J Am Geriatr Soc 59:101-106

78. Shardell M, Hicks GE, Miller RR, Kritchevsky S, Andersen D, Bandinelli S, Cherubini A, Ferrucci L (2009) Association of low vitamin $\mathrm{D}$ levels with the frailty syndrome in men and women. J Gerontol A Biol Sci Med Sci 64:69-75

79. Lips P (2006) Vitamin D physiology. Progr Biophys Mol Biol 92:4-8

80. Blaum CS, Xue QL, Michelon E, Semba RD, Fried LP (2005) The association between obesity and the frailty syndrome in older women: the women's health and aging studies. J Am Geriatr Soc 53:927-934

81. Hubbard RE, Lang IA, Llewellyn DJ, Rockwood K (2010) Frailty, body mass index, and abdominal obesity in older people. J Gerontol A Biol Sci Med Sci 65:377-381

82. Fried LP, Borhani NO, Enright P, Furberg CD, Gardin JM, Kronmal RA, Kuller LH, Manolio TA, Mittelmark MB, Newman A et al (1991) The cardiovascular health study: design and rationale. Ann Epidemiol 1:263-276

83. Cawthon PM, Marshall LM, Michael Y, Dam TT, Ensrud KE, Barrett-Connor E, Orwoll ES (2007) Frailty in older men: prevalence, progression, and relationship with mortality. J Am Geriatr Soc 55:1216-1223

84. Ble A, Cherubini A, Volpato S, Bartali B, Walston JD, Windham BG, Bandinelli S, Lauretani F, Guralnik JM, Ferrucci L (2006) Lower plasma vitamin E levels are associated with the 
frailty syndrome: the InCHIANTI study. J Gerontol A Biol Sci Med Sci 61:278-283

85. Santos-Eggimann B, Cuenoud P, Spagnoli J, Junod J (2009) Prevalence of frailty in middle-aged and older communitydwelling Europeans living in 10 countries. J Gerontol A Biol Sci Med Sci 64:675-681

86. Romero-Ortuno R, Walsh CD, Lawlor BA, Kenny RA (2010) A frailty instrument for primary care: findings from the survey of health, ageing and retirement in Europe (SHARE). BMC Geriatr 10:57

87. Rolfson DB, Majumdar SR, Tsuyuki RT, Tahir A, Rockwood K (2006) Validity and reliability of the Edmonton frail scale. Age Ageing 35:526-529

88. Bergman H, Béland F, Karunananthan S, Hummel S, Hogan D, Wolfson C (2004) Développement d'un cadre de travail pour comprendre et étudier la fragilité. Gerontol Soc 109:15

89. Strawbridge WJ, Shema SJ, Balfour JL, Higby HR, Kaplan GA (1998) Antecedents of frailty over three decades in an older cohort. J Gerontol B Psychol Sci Soc Sci 53:S9-S16

90. Avila-Funes JA, Amieva H, Barberger-Gateau P, Le Goff M, Raoux N, Ritchie K, Carriere I, Tavernier B, Tzourio C, Gutierrez-Robledo LM, Dartigues JF (2009) Cognitive impairment improves the predictive validity of the phenotype of frailty for adverse health outcomes: the three-city study. J Am Geriatr Soc 57:453-461

91. Rockwood K, Mitnitski A (2007) Frailty in relation to the accumulation of deficits. J Gerontol A Biol Sci Med Sci 62:722-727

92. Searle SD, Mitnitski A, Gahbauer EA, Gill TM, Rockwood K (2008) A standard procedure for creating a frailty index. BMC Geriatr 8:24

93. van Kan GA, Rolland Y, Houles M, Gillette-Guyonnet S, Soto M, Vellas B (2010) The assessment of frailty in older adults. Clin Geriatr Med 26:275-286

94. Rockwood K, Andrew M, Mitnitski A (2007) A comparison of two approaches to measuring frailty in elderly people. J Gerontol A Biol Sci Med Sci 62:738-743

95. Abellan van Kan G, Rolland Y, Bergman H, Morley JE, Kritchevsky SB, Vellas B (2008) The IANA ask force on frailty assessment of older people in clinical practice. J Nutr Health Aging 12:29-37

96. Cigolle CT, Ofstedal MB, Tian Z, Blaum CS (2009) Comparing models of frailty: the health and retirement study. J Am Geriatr Soc 57:830-839

97. van Iersel MB, Rikkert MG (2006) Frailty criteria give heterogenous results when applied in clinical practice. J Am Geriatr Soc 54:728-729

98. Hubbard RE, O'Mahony MS, Woodhouse KW (2009) Characterising frailty in the clinical setting-a comparison of different approaches. Age Ageing 38:115-119

99. Cooper C, Dere W, Evans W, Kanis JA, Rizzoli R, Sayer AA, Sieber CC, Kaufman JM, Abellan van Kan G, Boonen S, Adachi J, Mitlak B, Tsouderos Y, Rolland Y, Reginster JY (2012) Frailty and sarcopenia: definitions and outcome parameters. Osteoporos Int 23(7):1839-1848

100. Rockwood K (2005) What would make a definition of frailty successful? Age Ageing 34:432-434

101. Gobbens RJ, Luijkx KG, Wijnen-Sponselee MT, Schols JM (2010) Toward a conceptual definition of frail community dwelling older people. Nurs Outlook 58:76-86

102. Rolland Y, Abellan van Kan G, Benetos A, Blain H, Bonnefoy M, Chassagne P, Jeandel C, Laroche M, Nourhashemi F, Orcel P, Piette F, Ribot C, Ritz P, Roux C, Taillandier J, Tremollieres F, Weryha G, Vellas B (2008) Frailty, osteoporosis and hip fracture: causes, consequences and therapeutic perspectives. J Nutr Health Aging 12:335-346
103. Gill TM, Gahbauer EA, Allore HG, Han L (2006) Transitions between frailty states among community-living older persons. Arch Intern Med 166:418-423

104. Theou O, Stathokostas L, Roland KP, Jakobi JM, Patterson C, Vandervoort AA, Jones GR (2011) The effectiveness of exercise interventions for the management of frailty: a systematic review. J Aging Res 2011:569194

105. Liu CJ, Latham NK (2009) Progressive resistance strength training for improving physical function in older adults. Cochrane Database Syst Rev 3:CD002759

106. Fielding RA, LeBrasseur NK, Cuoco A, Bean J, Mizer K, Fiatarone Singh MA (2002) High-velocity resistance training increases skeletal muscle peak power in older women. $\mathrm{J}$ Am Geriatr Soc 50:655-662

107. Roelants M, Delecluse C, Verschueren SM (2004) Whole-bodyvibration training increases knee-extension strength and speed of movement in older women. J Am Geriatr Soc 52:901-908

108. Bogaerts A, Delecluse C, Claessens AL, Coudyzer W, Boonen S, Verschueren SM (2007) Impact of whole-body vibration training versus fitness training on muscle strength and muscle mass in older men: a 1-year randomized controlled trial. J Gerontol A Biol Sci Med Sci 62:630-635

109. Howe TE, Shea B, Dawson LJ, Downie F, Murray A, Ross C, Harbour RT, Caldwell LM, Creed G (2011) Exercise for preventing and treating osteoporosis in postmenopausal women. Cochrane Database Syst Rev 7:CD000333

110. Whiteford J, Ackland T, Dhaliwal S, James A, Woodhouse J, Price R (2010) Effects of a 1-year randomized controlled trial of resistance training on lower limb bone and muscle structure and function in older men. Osteoporos Int 21:8

111. Wysocki A, Butler M, Shamliyan T, Kane RL (2011) Wholebody vibration therapy for osteoporosis: state of the science. Ann Intern Med 155(680-686):W206-W613

112. Sattler FR, Castaneda-Sceppa C, Binder EF, Schroeder ET, Wang Y, Bhasin S, Kawakubo M, Stewart Y, Yarasheski KE, Ulloor J, Colletti P, Roubenoff R, Azen SP (2009) Testosterone and growth hormone improve body composition and muscle performance in older men. J Clin Endocrinol Metab 94:1991-2001

113. Morley JE (2010) Anabolic steroids and frailty. J Am Med Dir Assoc 11:533-536

114. Srinivas-Shankar U, Roberts SA, Connolly MJ, O'Connell MD, Adams JE, Oldham JA, Wu FC (2010) Effects of testosterone on muscle strength, physical function, body composition, and quality of life in intermediate-frail and frail elderly men: a randomized, double-blind, placebo-controlled study. J Clin Endocrinol Metab 95:639-650

115. Travison TG, Basaria S, Storer TW, Jette AM, Miciek R, Farwell WR, Choong K, Lakshman K, Mazer NA, Coviello AD, Knapp PE, Ulloor J, Zhang A, Brooks B, Nguyen AH, Eder R, LeBrasseur N, Elmi A, Appleman E, Hede-Brierley L, Bhasin G, Bhatia A, Lazzari A, Davis S, Ni P, Collins L, Bhasin S (2011) Clinical meaningfulness of the changes in muscle performance and physical function associated with testosterone administration in older men with mobility limitation. J Gerontol A Biol Sci Med Sci 66:1090-1099

116. Kenny AM, Kleppinger A, Annis K, Rathier M, Browner B, Judge JO, McGee D (2010) Effects of transdermal testosterone on bone and muscle in older men with low bioavailable testosterone levels, low bone mass, and physical frailty. J Am Geriatr Soc 58:1134-1143

117. Kanis JA, Bianchi G, Bilezikian JP, Kaufman JM, Khosla S, Orwoll E, Seeman E (2011) Towards a diagnostic and therapeutic consensus in male osteoporosis. Osteoporos Int 22: 2789-2798

118. Isidori AM, Giannetta E, Greco EA, Gianfrilli D, Bonifacio V, Isidori A, Lenzi A, Fabbri A (2005) Effects of testosterone on 
body composition, bone metabolism and serum lipid profile in middle-aged men: a meta-analysis. Clin Endicrinol 63:280-293

119. Kaufman JM, Vermeulen A (2005) The decline of androgen levels in elderly men and its clinical and therapeutic implications. Endocr Rev 26:833-876

120. Basaria S, Coviello AD, Travison TG, Storer TW, Farwell WR, Jette AM, Eder R, Tennstedt S, Ulloor J, Zhang A, Choong K, Lakshman KM, Mazer NA, Miciek R, Krasnoff J, Elmi A, Knapp PE, Brooks B, Appleman E, Aggarwal S, Bhasin G, Hede-Brierley L, Bhatia A, Collins L, LeBrasseur N, Fiore LD, Bhasin S (2010) Adverse events associated with testosterone administration. N Engl J Med 363:109-122

121. Fernandez-Balsells MM, Murad MH, Lane M, Lampropulos JF, Albuquerque F, Mullan RJ, Agrwal N, Elamin MB, GallegosOrozco JF, Wang AT, Erwin PJ, Bhasin S, Montori VM (2010) Clinical review 1 . Adverse effects of testosterone therapy in adult men: a systematic review and meta-analysis. J Clin Endocrinol Metab 95:2560-2575

122. Calof OM, Singh AB, Lee ML, Kenny AM, Urban RJ, Tenover JL, Bhasin S (2005) Adverse events associated with testosterone replacement in middle-aged and older men: a meta-analysis of randomized, placebo-controlled trials. J Gerontol A Biol Sci Med Sci 60:1451-1457

123. Bhasin S, Cunningham GR, Hayes FJ, Matsumoto AM, Snyder PJ, Swerdloff RS, Montori VM (2010) Testosterone therapy in men with androgen deficiency syndromes: an endocrine society clinical practice guideline. J Clin Endocrinol Metab 95: 2536-2559

124. Annweiler C, Schott AM, Berrut G, Fantino B, Beauchet O (2009) Vitamin D-related changes in physical performance: a systematic review. J Nutr Health Aging 13:893-898

125. Stockton KA, Mengersen K, Paratz JD, Kandiah D, Bennell KL (2011) Effect of vitamin D supplementation on muscle strength: a systematic review and meta-analysis. Osteoporos Int 22: 859-871

126. Bischoff-Ferrari HA, Dawson-Hughes B, Staehelin HB, Orav JE, Stuck AE, Theiler R, Wong JB, Egli A, Kiel DP, Henschkowski J (2009) Fall prevention with supplemental and active forms of vitamin D: a meta-analysis of randomised controlled trials. Br Med J 339:b3692

127. Ceglia L (2008) Vitamin D and skeletal muscle tissue and function. Mol Aspects Med 29:407-414

128. Lin R, White JH (2004) The pleiotropic actions of vitamin D. Bioessays 26:21-28

129. Annweiler C, Schott AM, Berrut G, Chauvire V, Le Gall D, Inzitari M, Beauchet O (2010) Vitamin D and ageing: neurological issues. Neuropsychobiology 62:139-150

130. Lyles KW, Colon-Emeric CS, Magaziner JS, Adachi JD, Pieper CF, Mautalen C, Hyldstrup L, Recknor C, Nordsletten L, Moore KA, Lavecchia C, Zhang J, Mesenbrink P, Hodgson PK, Abrams K, Orloff JJ, Horowitz Z, Eriksen EF, Boonen S (2007) Zoledronic acid and clinical fractures and mortality after hip fracture. N Engl J Med 357:1799-1809

131. Tang BM, Eslick GD, Nowson C, Smith C, Bensoussan A (2007) Use of calcium or calcium in combination with vitamin $\mathrm{D}$ supplementation to prevent fractures and bone loss in people aged 50 years and older: a meta-analysis. Lancet 370:657-666

132. Hennessey JV, Chromiak JA, DellaVentura S, Reinert SE, Puhl J, Kiel DP, Rosen CJ, Vandenburgh H, MacLean DB (2001) Growth hormone administration and exercise effects on muscle fiber type and diameter in moderately frail older people. J Am Geriatr Soc 49:852-858

133. Merriam GR, Schwartz RS, Vitiello MV (2003) Growth hormone-releasing hormone and growth hormone secretagogues in normal aging. Endocrine 22:41-48
134. Hersch EC, Merriam GR (2008) Growth hormone (GH)releasing hormone and $\mathrm{GH}$ secretagogues in normal aging: fountain of youth or pool of tantalus? Clin Interv Aging 3: $121-129$

135. Liu H, Bravata DM, Olkin I, Nayak S, Roberts B, Garber AM, Hoffman AR (2007) Systematic review: the safety and efficacy of growth hormone in the healthy elderly. Ann Intern Med 146:104-115

136. White HK, Petrie CD, Landschulz W, MacLean D, Taylor A, Lyles K, Wei JY, Hoffman AR, Salvatori R, Ettinger MP, Morey MC, Blackman MR, Merriam GR (2009) Effects of an oral growth hormone secretagogue in older adults. J Clin Endocrinol Metab 94:1198-1206

137. Nass R, Pezzoli SS, Oliveri MC, Patrie JT, Harrell FE Jr, Clasey JL, Heymsfield SB, Bach MA, Vance ML, Thorner MO (2008) Effects of an oral ghrelin mimetic on body composition and clinical outcomes in healthy older adults: a randomized trial. Ann Intern Med 149:601-611

138. Milne AC, Potter J, Avenell A (2005) Protein and energy supplementation in elderly people at risk from malnutrition. Cochrane Database Syst Rev 2:CD003288

139. Seeman E, Vellas B, Benhamou C, Aquino JP, Semler J, Kaufman JM, Hoszowski K, Varela AR, Fiore C, Brixen K, Reginster JY, Boonen S (2006) Strontium ranelate reduces the risk of vertebral and nonvertebral fractures in women eighty years of age and older. J Bone Miner Res 21:1113-1120

140. Colon-Emeric CS, Mesenbrink P, Lyles KW, Pieper CF, Boonen S, Delmas P, Eriksen EF, Magaziner J (2010) Potential mediators of the mortality reduction with zoledronic acid after hip fracture. J Bone Miner Res 25:91-97

141. Cooper C, Atkinson EJ, Jacobsen SJ, O'Fallon WM, Melton LJ 3rd (1993) Population-based study of survival after osteoporotic fractures. Am J Epidemiol 137:1001-1005

142. Chrischilles EA, Butler CD, Davis CS, Wallace RB (1991) A model of lifetime osteoporosis impact. Arch Intern Med 151:2026-2032

143. Maggi S, Siviero P, Wetle T, Besdine RW, Saugo M, Crepaldi G (2010) A multicenter survey on profile of care for hip fracture: predictors of mortality and disability. Osteoporos Int 21:223231

144. Oleksik A, Lips P, Dawson A, Minshall ME, Shen W, Cooper C, Kanis J (2000) Health-related quality of life in postmenopausal women with low BMD with or without prevalent vertebral fractures. J Bone Miner Res 15:1384-1392

145. Morley JE (2009) Developing novel therapeutic approaches to frailty. Curr Pharm Des 15:3384-3395

146. Sakuma K, Yamaguchi A (2012) Novel intriguing strategies attenuating to sarcopenia. J Aging Res 2012:251217

147. Onder G, Penninx BW, Balkrishnan R, Fried LP, Chaves PH, Williamson J, Carter C, Di Bari M, Guralnik JM, Pahor M (2002) Relation between use of angiotensin-converting enzyme inhibitors and muscle strength and physical function in older women: an observational study. Lancet 359:926-930

148. Velloso CP (2008) Regulation of muscle mass by growth hormone and IGF-I. Br J Pharmacol 154:557-568

149. Semba RD, Varadhan R, Bartali B, Ferrucci L, Ricks MO, Blaum C, Fried LP (2007) Low serum carotenoids and development of severe walking disability among older women living in the community: the women's health and aging study I. Age Ageing 36:62-67

150. Boonen S, Milisen K, Gielen E, Meeuwissen J, Dejaeger E, Sermon A, Lodewijkckx C, Vanhaecht K (2011) Farmacologische osteoporosebehandeling, valpreventieve maatregelen en geriatrische nazorg in het kader van een zorgpad voor heupfractuurpatiënten. Tijdschrift voor Geneeskunde 67:10

151. Van Craen K, Braes T, Wellens N, Denhaerynck K, Flamaing J, Moons P, Boonen S, Gosset C, Petermans J, Milisen K (2010) 
The effectiveness of inpatient geriatric evaluation and management units: a systematic review and meta-analysis. J Am Geriatr Soc 58:83-92

152. Mayer-Davis EJ, D’Agostino R Jr, Karter AJ, Haffner SM, Rewers MJ, Saad M, Bergman RN (1998) Intensity and amount of physical activity in relation to insulin sensitivity: the insulin resistance atherosclerosis study. J Am Med Assoc 279:669-674

153. Walsh NP, Gleeson M, Shephard RJ, Woods JA, Bishop NC, Fleshner M, Green C, Pedersen BK, Hoffman-Goetz L, Rogers CJ, Northoff H, Abbasi A, Simon P (2011) Position statement, part 1. Immune function and exercise. Exerc Immunol Rev 17:6-63

154. De Palo EF, Antonelli G, Gatti R, Chiappin S, Spinella P, Cappellin E (2008) Effects of two different types of exercise on GH/IGF axis in athletes. Is the free/total IGF-I ratio a new investigative approach? Clin Chimica Acta 387:71-74

155. Tremblay MS, Copeland JL, Van Helder W (2004) Effect of training status and exercise mode on endogenous steroid hormones in men. J Appl Physiol 96:531-539
156. Li J, Siegrist J (2012) Physical activity and risk of cardiovascular disease - a meta-analysis of prospective cohort studies. Int J Environ Res Public Health 9:391-407

157. Tan EJ, Xue QL, Li T, Carlson MC, Fried LP (2006) Volunteering: a physical activity intervention for older adults- the experience corps program in Baltimore. J Urban Health 83: 954-969

158. Kenny AM, Bellantonio S, Gruman CA, Acosta RD, Prestwood KM (2002) Effects of transdermal testosterone on cognitive function and health perception in older men with low bioavailable testosterone levels. J Gerontol A Biol Sci Med Sci 57:M321-M325

159. Sanders KM, Stuart AL, Williamson EJ, Simpson JA, Kotowicz MA, Young D, Nicholson GC (2010) Annual high-dose oral vitamin $\mathrm{D}$ and falls and fractures in older women: a randomized controlled trial. J Am Med Assoc 303:1815-1822 
Reproduced with permission of the copyright owner. Further reproduction prohibited without permission. 